\title{
胎内音に対する新生览の聴覚反応に関する研究
}

\author{
和歌山県立医科大学耳鼻咽喉科学教室（主任：田端敏秀教授） \\ 加藤 䙾
}

\section{A STUDY OF THE AUDITORY RESPONSES TO INTRA-UTERINE SOUND IN THE FIRST FEW MONTHS AFTER BIRTH}

YUTAKA KATOH, M.D.

Department of Otorhinolaryngology, Wakayama Medical College, Wakayama

The auditory responses of infants until 3 months after birth were examined using the doll "Nenkororin" which contains a tape recorder of the intrauterine sound (IUS). The purpose of this study was to assess the applicability of these responses to screening of infants with severe hearing impairment. The results are summarized as follows.

1. The IUS with $1 / 3$-octaval audiofrequency of $400 \mathrm{~Hz} \sim 4 \mathrm{kHz}$ was presented to 152 neonates. Positive responses showing alert inactivity were obtained in 148 infants, but negative responses in 2 neonates. 2 infants were undetermined. The neonates showed negative responses had severe hearing impairment with comparison of ABR. ABR was also carried out in 69 of the 152 infants. The results of ABR well agreed with those of the IUS test.

2. A typical reaction of neonates who stopped crying and assumed a state of alert inactivity in responses to the IUS was demonstrated until approximately one month after birth. At the end of the first month after birth, the threshold of this reaction grew smaller than that of the one-week period after birth. The latent time of this reaction also tended to become shorter.

3. The infants mostly failed to respond to the $1 / 3$-octaval noise consisting of $0.5,1.0,2.0$, 4. $0 \mathrm{kHz}$ extracted from the IUS. From the experiment using high and low pass noise components extracted from the IUS. High response were obtained at low frequency. band components below $1 \mathrm{kHz}$.

4. Public health nurses without experience of auditory test were requested to compare the reaction by the IUS test and an auditory reflex test using tongue-clicking, whistling and papercrumpling sounds. The IUS test was found to be easier for evaluation of the reactions than the other method of test.

From the above results it is concluded that the auditory response to the IUS was useful for screening of severe hearing impairment in neonates until one after birth.

Key words : 胎内音, 恥賞スクリーニング検査, 新生児

$\mathrm{ABR}$, 高度難聴

A $93-0268-20572$

緒言

近年, 難聴児の早期発見, 診断, おょびハビリテー
ションの重要性が認識されこの分野の充実が社会的

要請として重要な課題となってきている. 


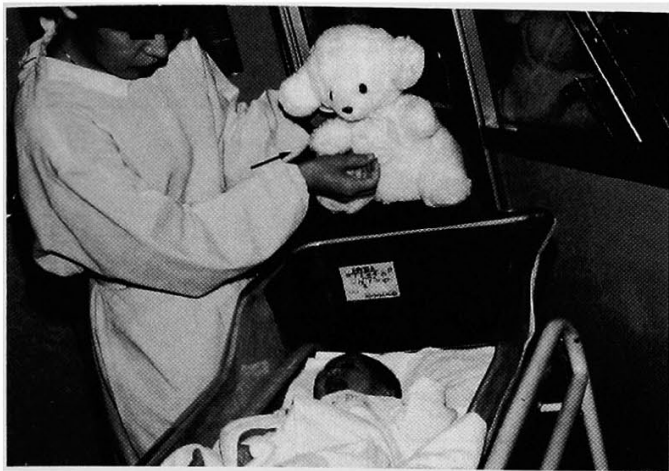

図 1 胎内音内藏人形“ねんころりん”(矢印) 用いての反応観察

難聴児の早期発見の第一歩は, 適正なスクリーニン グ検查を実施することから始まる，スクリーニング検 查としての基本は, 悉皆検查にある. その条件として は, 誰でも簡単に実施可能であること, 器具としても 手軽に入手できること，またどこででも行え，その上 にスクリーニングの精度 (鋭敏度: sensitivity, および 特異度：specificity)が高いことなどが要求される.現 在, 新生児聴力スクリーニング検査法には, 各種音源 を用いた聴性反射直接観察法 ${ }^{1)}$, 自動記録法としての Crib-0-Gram ${ }^{2}$, Neonatal Sensory Response Meter を用いる方法 ${ }^{3)}$ ，また聴性脳幹反応(ABR)などがある. しかしこれらの方法をスクリーニングとして悉皆検査 に用いるには上記の条件を十分にみたしているとは言 い難く，そのためリスク児に対する精密検査に利用さ れているのが現状である．著者はこのような条件をほ ほ満たす新生児期の聴覚スクリーニング検査として, 室岡 ${ }^{4)}$ の「泣いている新生児に胎内音を聴かせると泣 き止み“alert inactivity”になる.」との反応が使えな いかについて研究を重ね ${ }^{5) 6}$ ，その結果，ほほ満足しう る結果を得たので報告する.

\section{対象と方法}

（I） 胎内音の周波数分析

室岡の監修により製作され，既に市販されている胎 内音発生装置を内臟した人形“ねんころりん”の周波 数分析を和歌山県立医科大学衛生学教室で行った。 そ の際用いた装置は RION K.K. REALTIME ANALYZER SA-24, RION K.K. IMPULSE PRECISION SOUND LEVEL METER NA-61 であった.

(II） 胎内音に対する新生児の聴覚反応 ${ }^{5)}$

対象：生後 2 時問目から31日目までの新生児152名

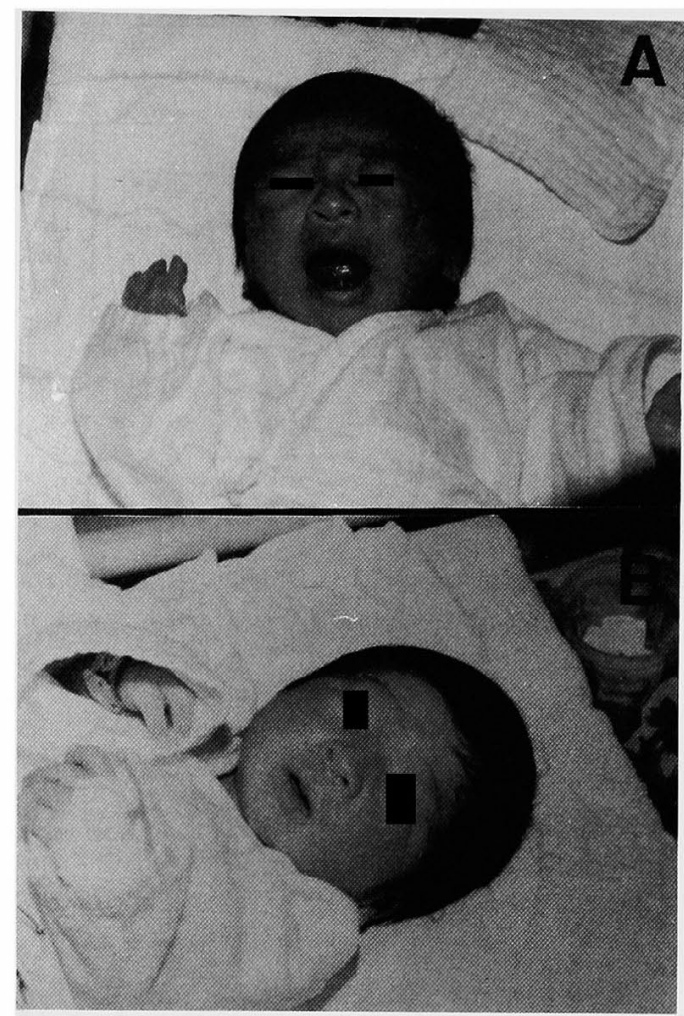

図 2 A：号泣時, B：反応時

で，出生時体重は $1,290 \mathrm{~g}$ から $4,085 \mathrm{~g}$ である。そのな かには未熟児14名も含まれていた.これらの児の耳介, 外耳道, 鼓膜所見は正常であった。

方法：検查は当科検査室，または和歌山赤十字病院 産婦人科新生児隔離室で実施した。

上記の被験児が空腹で泣いている時に, 鼻根部より 約 $30 \mathrm{~cm}$ 離れたところから胎内音を呈示し，その反応 を観察した（図 1 )。音圧は鼻根部で平均 $80 \mathrm{dBSPL}(\mathrm{A}$

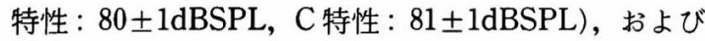
平均 90dBSPL (A 特性：88 89dBSPL, C 特性：89 〜90dBSPL) となるようにつまみの位置を決め, これ らに反応しない時には音源を近づけた，反応陽性とは 音源呈示後60秒以内に明らかに泣き止んだ場合(図 2) とした。 な打 1 分間胎内音を聴かせても泣き止まない 場合には，最低 3 回同じ音圧で試み，なお反応の無い 場合を陰性とした，反応陽性の場合には，音源を呈示 して泣き止むまでの潜時も測定した。

152名のうち69名については ABRによる聴覚反応 も測定した。 ABR は TEREDYNE TA-1000または CADWELL CA-5200 を用いて測定した.TA-1000の 


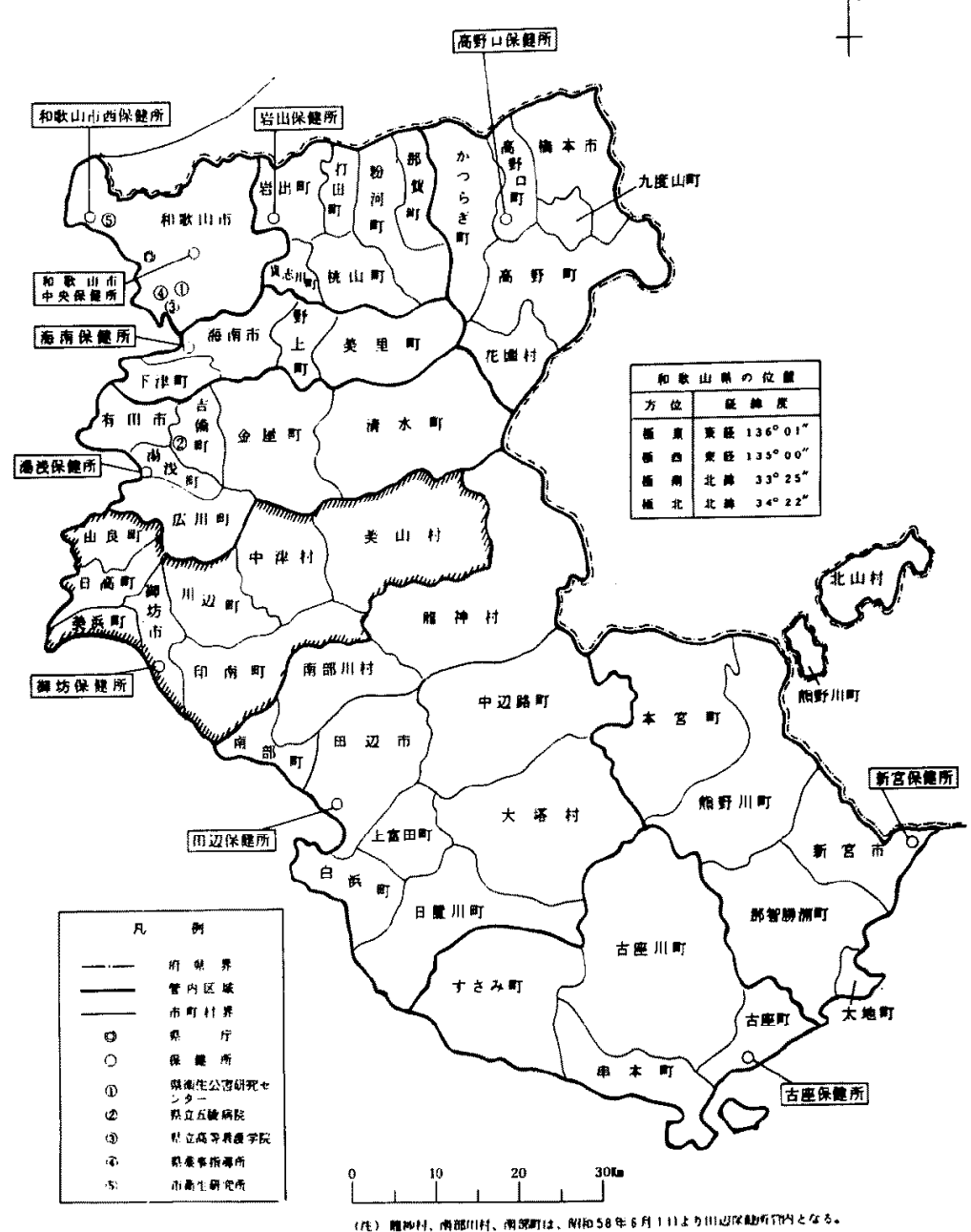

図 3 和歌山県御坊保健所管内（斜線部）

測定条件は, 刺激音 $2 \mathrm{kHz}$ Logon, 刺激間隔 20 回/秒, フィルターパス 30 1500Hz，加算回数 1 , 200回とし た、CA-5200ではクリック音刺激，刺激間隔 11.29 PULS/sec. フィルターパス $100 \sim 3000 \mathrm{~Hz}$, 加算回数 2,000回で時に 2 チャンネルを用いた。

(III) 胎内音に対する聴賞反応の経日的変化 ${ }^{6)}$

対象：耳鏡所見正常な出生時体重 2,640g から $3,566 \mathrm{~g}$ خ゙の健康新生児 15 名.

方法：これらの児すべてが生後 1 週間以内に BOA や胎内音に対して反応陽性であり，またABRにも $50 \mathrm{dBHL}$ 以上で $\mathrm{V}$ 波が認められることを TELEDYNE TA-1000で確かめた。 その後 1 力月目, 2 力月目, 3 力月目に扔ける反応樣式, 反応潜時, 音
圧につき観察した，検査は生後 1 週間以内は新生児隔 離室で，その後は各被験児の家庭の静かな部屋で実拖 した.

(IV) 胎内音の狭帯域成分に対する聴性反応の検討 胎内音からフィルターを使って周波数をさらに狭带 域にすることにより，従来の純音聴力㮩查のごとくそ れぞれの帯域ごとの域值決定に使えないかどうか，末 た新生児の反応が主にどの周波数带域の音に由来して いるかどうかについて検討した。

音源：(1) 実験（I）で求めた胎内音の周波数領域加 ら成分テープとして中心周波数が $0.5 \mathrm{kHz}, 1 \mathrm{kHz}$, $2 \mathrm{kHz}, 4 \mathrm{kHz}$ の1/3オクターブバンド成分を抽出した テープを作成.この時使用した装置は1/3オクターブバ 
表 1 御坊保健所管内自治体ごとの被験児数

\begin{tabular}{|c|c|c|c|}
\hline & 該当者 & 実施者 & 末実施 \\
\hline 御坊市 & 114 & 111 & 3 \\
\hline 美浜町 & 25 & 24 & 1 \\
\hline 日高町 & 22 & 21 & 1 \\
\hline 由良町 & 23 & 21 & 2 \\
\hline 川辺町 & 21 & 18 & 3 \\
\hline 印南町 & 34 & 26 & 8 \\
\hline 中津村 & 7 & 3 & 4 \\
\hline \multirow[t]{2}{*}{ 美山村 } & 1 & 1 & 0 \\
\hline & 247 & 225 & 22 \\
\hline \multicolumn{4}{|c|}{ 未実施については } \\
\hline 新生児死亡 & 2 & & \\
\hline 入 院 中 & 1 & & \\
\hline 末 訪 問 & $\begin{array}{l}19 \\
\text { (里㷌 }\end{array}$ & どで訪䦓 & が不在) \\
\hline
\end{tabular}

ンドフィルター(RION NX-02), ポータブルカセット レコーダー (AIWA CS-75X) である. (2) $0.5 \mathrm{kHz}$, $1 \mathrm{kHz}, 2 \mathrm{kHz}, 4 \mathrm{kHz}$ の High pass filter を通した成分 テープ (以下High pass noise と略記), さらに $0.5 \mathrm{kHz}, 1 \mathrm{kHz}, 2 \mathrm{kHz}, 4 \mathrm{kHz}$ Low pass filter を通 した成分テープ(以下 Low pass noise と略記)もDual Decade Filter 24dB/oct. (NF 社 FV-624), 騒音計 (RION NA-20), カセットデッキ(AIWA CS-75X) を用いて作成した。

対象：生後 2 日目から12日目までの新生児37名（全 員, 出生時体重 $2,500 \mathrm{~g}$ 以上) である.

方法：これらの被験児はまず胎内音 $(90 \mathrm{~dB})$ に全員 が陽性を示し ABR (TELEDYNE TA-1000)にも $50 \mathrm{~dB}$ 以上で陽性であることを確かめた。そのうちの 25名には，音源(1)のテープを泣いている時に聴かし， 他の12名には(2)で作成された High pass noise 4 種, Low pass noise 4 種を用いてその反応を観察した。 これらの検查は新生览隔離室で行った。

（V）他の音源による聴性反射との反応率の比較 一ことに保健婦活動の一環として一

音源: 胎内音, 舌うち音, ホイッスル音, 紙もみ音 を用いた。

対象：和歌山県御坊保健所管内（図 3) にて昭和60 年8月1日から10月30日の間に出生した247名中225名 が被験児となった（表 1 ）。

方法：検查は管内の19名の保健婦が新生児初回家庭 訪問の際に各児の家庭の静かな部屋で実施した。

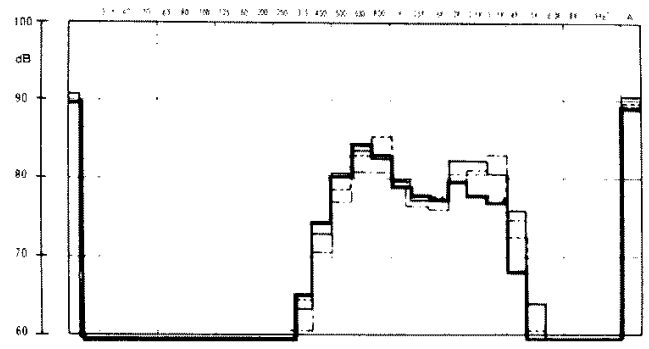

図 4 胎内音の周波数分析 (warble toneである ため実線や破線のごとくなる

胎内音の呈示音圧は被験児の耳元で約 $90 \mathrm{dBSPL} と$ した。 その反応は, 典型的には 1 分以内に泣き止んで alert inactivity な状態になるが, 今回の調查では泣き 止んだり泣き声が弱まるとか音源探索反応も反応陽性 とした。

舌うち音は、鈴木の方法”に従い, 寝入りばなに約 $50 \mathrm{~cm}$ 離れた位置より音を発生するようにした，その 音圧は約 50〜 55dBSPLである.ホイッスル音につい ては，その周波数が $2500 \mathrm{~Hz}$ 近辺のものを用いた。音圧 は約 90dBSPL とした。紙もみ音は広範囲の周波数を

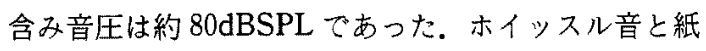
もみ音に関しては安静時に検查を実施するようにし た。これらの胎内音以外の音に対する反応はモロー反 射, 覚醒反射, 瞬目反射, 音源探索反応などの有無に ついて観察された.

\section{成 績}

\section{（I）胎内音の周波数分析}

胎内音は 1 分間に144回の拍動を持つwarble tone

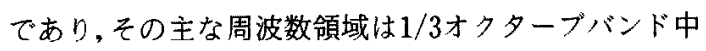
心周波数 $0.4 \mathrm{kHz}$ から $4 \mathrm{kHz}$ の成分で構成されている ことが分かった5!（図 4)

(II) 胎内音に対する新生児の聴覚反応 ${ }^{5)}$

被験児152名のうち148名が胎内音に対し, 明らかに 反応陽性であった。反応陰性児は 2 名, また胎内音に 反応を示したのか自然に泣き止んだのか判断に迷った 児が 2 名検出された(判定不能児)。表 2 , 表 3 は被験 新生児の検査時期と方法, 生後日数と胎内音に対する 反心の結果を示したものである。

反応陰性児 2 名は, 男女の双生児 (A：令, B：우) であり，母親が妊娠 8 週目に風疹に雁患したという risk factor を持っていた。図 $5 ， 6$ はそれぞれの児の 生後11日目から約 6 力月後までのABRである. 両児

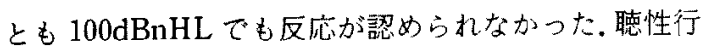


表 2 被験新生児の検查時期と方法

\begin{tabular}{|c|c|c|c|c|c|c|}
\hline 検査方法 & $\begin{array}{l}\text { 生 後 } \\
7 \text { 日以内 }\end{array}$ & $\begin{array}{l}8 \text { 日目〜 } \\
14 \text { 日以内 }\end{array}$ & $\begin{array}{l}15 \text { 日目 } \\
21 \text { 日以内 }\end{array}$ & $\begin{array}{l}22 \text { 日目 } \\
28 \text { 日以内 }\end{array}$ & $\begin{array}{l}29 \text { 日目 } \\
35 \text { 日以内 }\end{array}$ & 計 \\
\hline 胎内音のみ & 68 & 10 & 3 & 0 & 2 & 83 \\
\hline 胎内音, ABR & 53 & 11 & 2 & 2 & 1 & 69 \\
\hline 計 & 121 & 21 & 5 & 2 & 3 & 152 \\
\hline
\end{tabular}

表 3 被験児の生後日数と胎内音に対する反応

\begin{tabular}{|c|c|c|c|c|c|c|}
\hline 胎内音 & $\begin{array}{l}\text { 生 後 } \\
7 \text { 日以内 }\end{array}$ & $\begin{array}{l}8 \text { 日目 } \\
14 \text { 日以内 }\end{array}$ & $\begin{array}{l}\text { 15日目 } \\
21 \text { 日以内 }\end{array}$ & $\begin{array}{l}22 \text { 日目〜 } \\
28 \text { 日以内 }\end{array}$ & $\begin{array}{l}29 \text { 日目 } \\
35 \text { 日以内 }\end{array}$ & 計(名) \\
\hline 反応陽性児 & 120 & 18 & 5 & 2 & 3 & 148 \\
\hline 反応陰性児 & 0 & 2 & 0 & 0 & 0 & 2 \\
\hline 判定不能児 & 1 & 1 & 0 & 0 & 0 & 2 \\
\hline
\end{tabular}
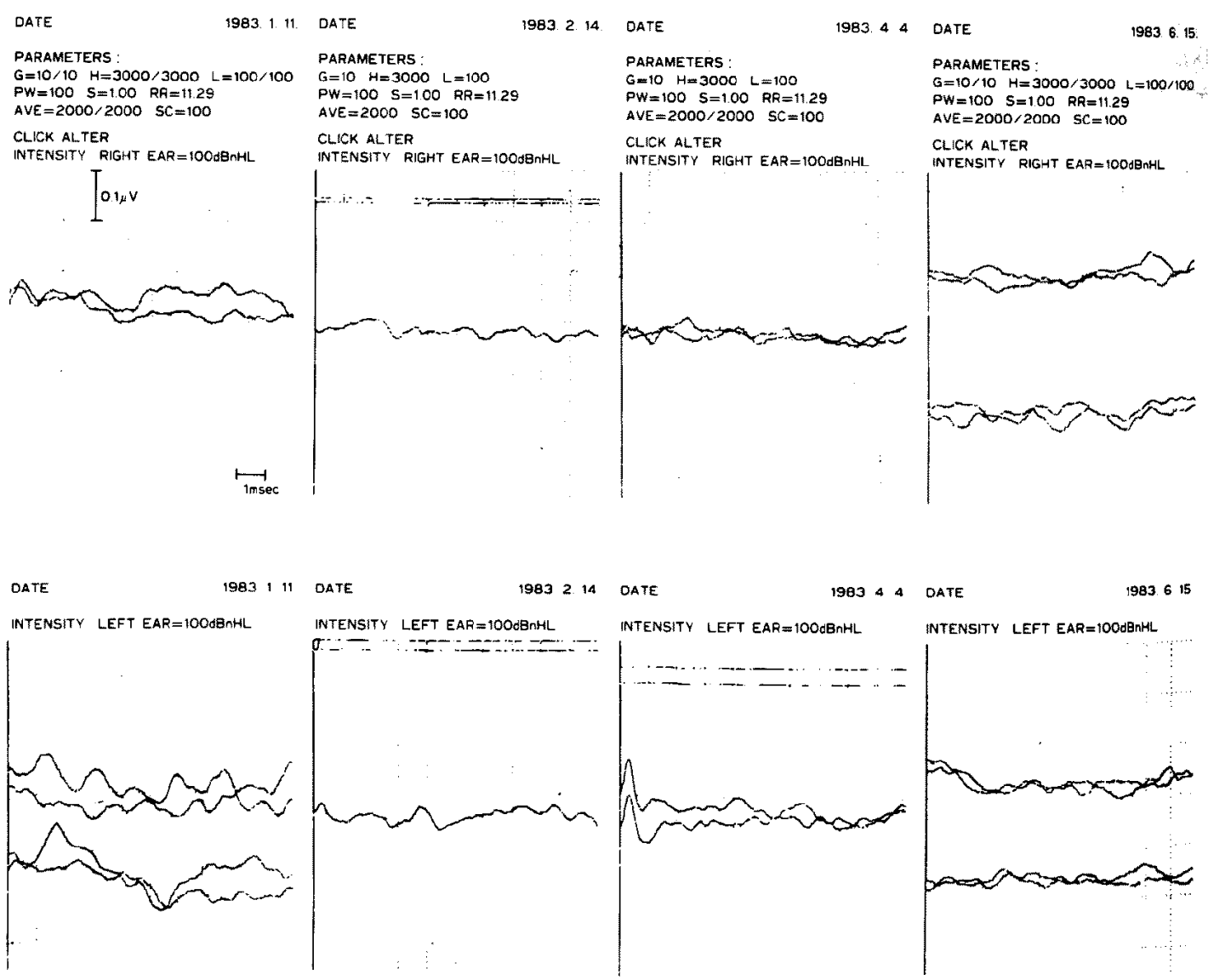

图 5 胎内音反応陰性双生児 $\mathrm{A}$ の ABR 


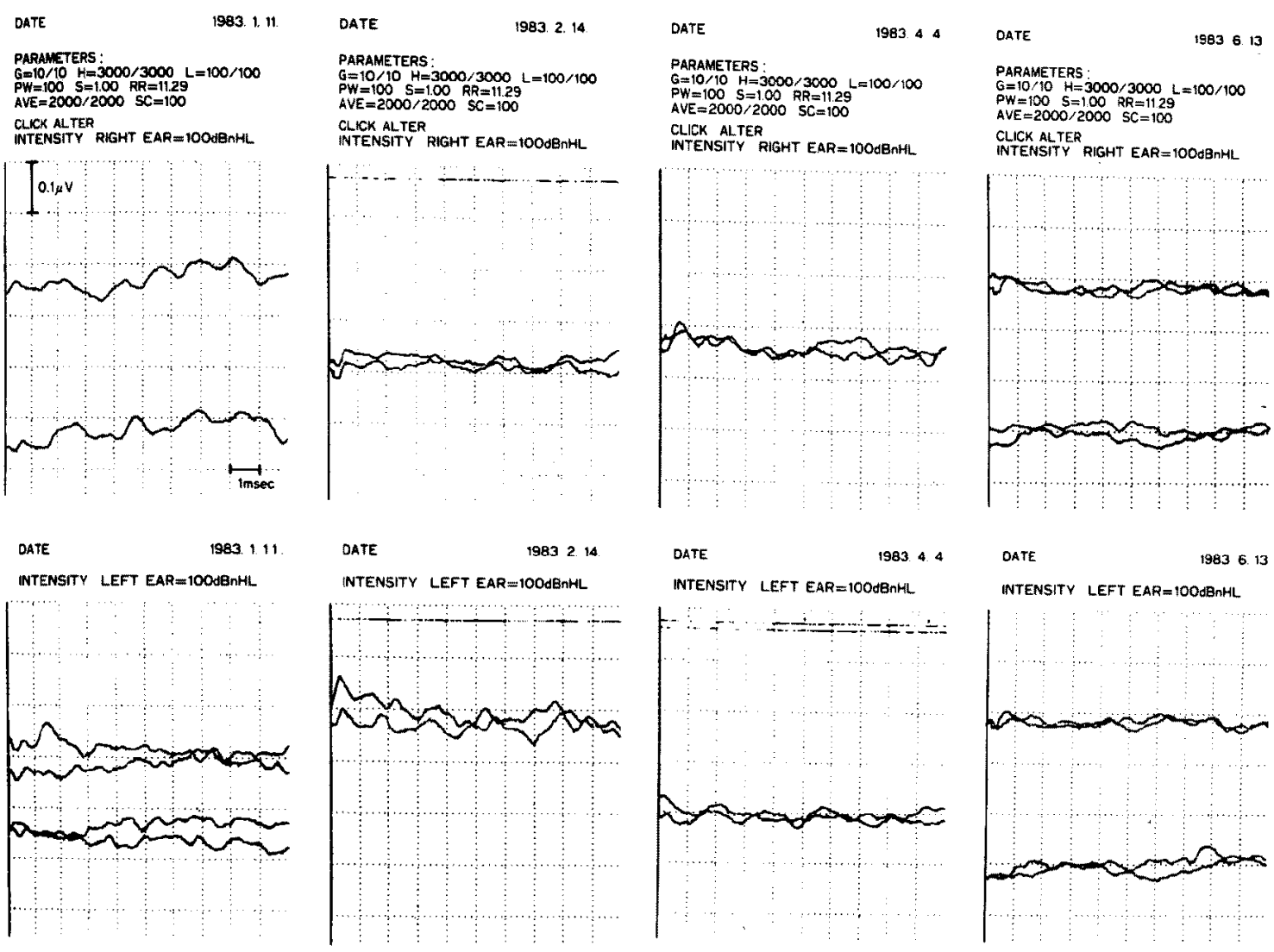

园 6 胎内音反応陰性双生览 $\mathrm{B}$ の $\mathrm{ABR}$

A

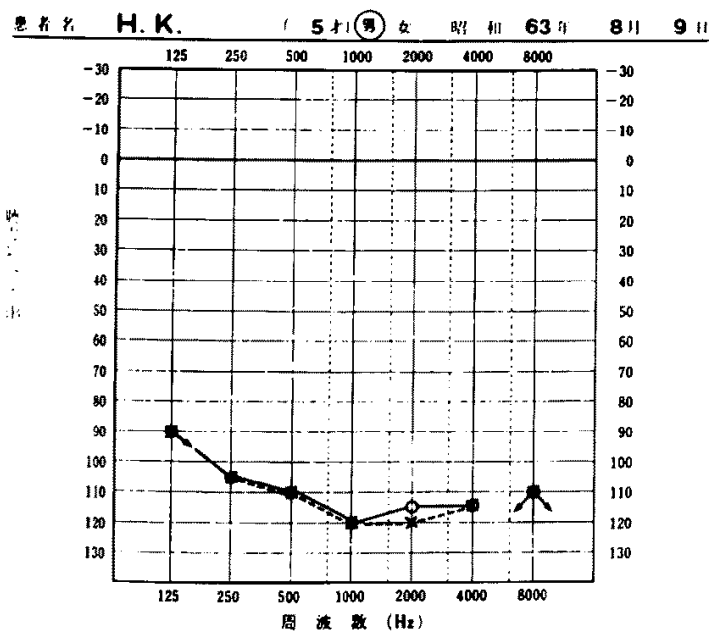

B

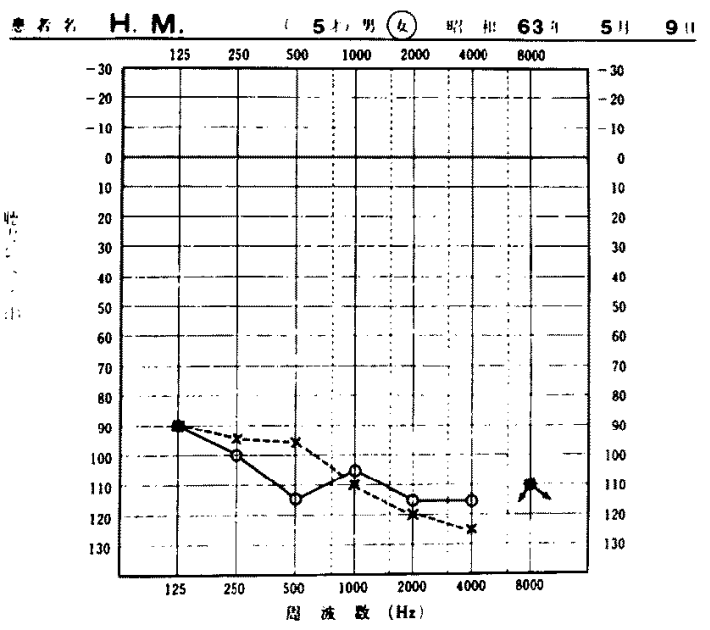

図 7 胎内音陰性双生児 A, B 5 歳時の恥力像 

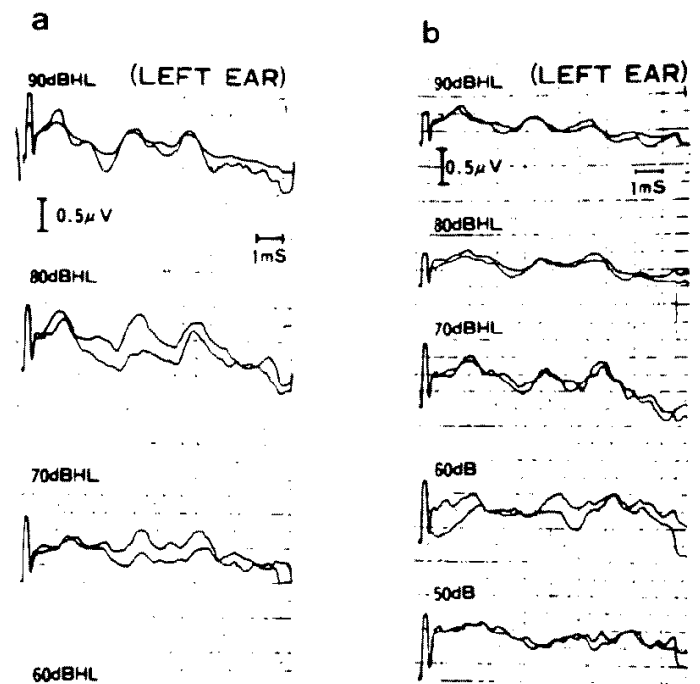

$600 \mathrm{BH}$
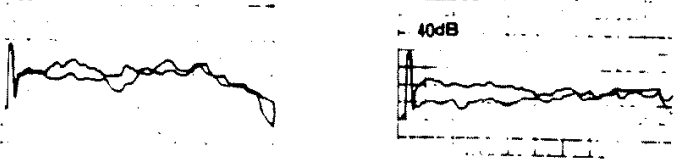

区8 胎内音反応判定不能児 $(a, b)$ の $A B R$

表 4 胎内音による反応と ABRの結果との関係

\begin{tabular}{ccccr}
\hline 反 & \multirow{2}{*}{ 応 } & (陽性) $^{\text {ABR }}$ & (陰性) & 計 \\
\hline 胎 & (陽性) & 65 & 0 & 65 \\
内 & (陰性) & 0 & 2 & 2 \\
音 & (不明) & 2 & 0 & 2 \\
\hline \multicolumn{2}{c}{ 計 } & 67 & 2 & 69 \\
\hline
\end{tabular}

動反応（BOA）を，太鼓やホイッスルで施行したが反 応はなかった。なおこれら 2 名の 5 歳時における標準 純音聴力検查の結果を図 7 に示す.

図8は胎内音に対する反応の有無を判断し難たかっ た判定不能児 2 名 $(\mathrm{a}, \mathrm{b})$ の ABRである.いずれも反 応は陽性であった，また BOAに対しても反応が認め られた。

$\mathrm{ABR}$ と本反応の比較：胎内音による反応と $\mathrm{ABR}$ の結果をまとめたものが表 4 である.これら両検查の 一致度は97.1\%であった。なおこの表における ABR 陽性児67名は平成元年 8 月の時点で全員 6 歳である が, 高度難聴のため補聴器を装用したり言語発達遅滞 を持った児はいない。

反応潜時：図 9 は反応陽性肾の潜時をヒストグラム に表したものである。その潜時は $2 \mathrm{sec}$.から $47 \mathrm{sec}$.の

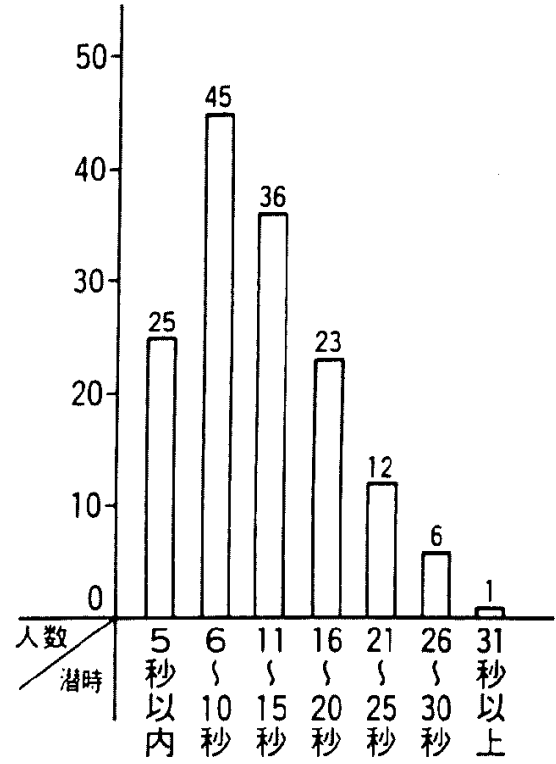

図 9 胎内音反応陽性児の反応潜時

表 5 胎内音反応陽性児の反応レベル

\begin{tabular}{cccc}
\hline 音圧レベル & 約 $80 \mathrm{~dB}$ & 約 $90 \mathrm{~dB}$ & $90 \mathrm{~dB}$ 以上 \\
\hline 人数(\%) & $30(20 \%)$ & $103(70 \%)$ & $15(10 \%)$ \\
\hline
\end{tabular}

間で認められ平均 $12 \mathrm{sec}$ （ $\mathrm{SD}= \pm 7.4 \mathrm{sec}$ ）であった。 音圧レベルとの関係：胎内音反応陽性児148名の最 小反応音圧レベルを表 5 に示す。約 80dBSPLて30名 (20\%)，90dBSPLでは70\%を占めていたのが特街的 であった。なお 90dBSPL 以上では148名全員が陽性反 応を示した。

(III) 胎内音に対する聴覚反応の経日的変化 ${ }^{6)}$

反応椂式と反応潜時: 生後 3 力月までの胎内音 (90dBSPL) に対する反応様式の変化と反応潜時の変 化を各被験児ごとに表 6 に，また典型的反応を示す時 期をまとめたものを表 7 に示した。

その結果, 胎内音に対し典型的な反応を全員が示し たのは生後 1 力までであった.

反応音圧の変動：表 8 は生後の時期別の胎内音最小 反応音圧レベルであり，典型的な反応を示す時期であ る生後 1 カ月まででは, 最小反応音圧は70dBSPL程 度まで検査可能であることが明らかとなった。

（IV）胎内音の狭帯域成分に対する聴性反応の検討 新生児25名の各1/3オクターブバンドノイズに対す る反応を表 9 に示す. 新生児はこれらのノイスにはほ とんど反応を示さず，純音聴力検查のごときそれぞれ 
表 6 生後 3 力月までの胎内音に対する反応様式の変化と反応潜時の変化

\begin{tabular}{|c|c|c|c|c|c|c|c|c|}
\hline \multirow{2}{*}{ 被験児 } & \multicolumn{2}{|c|}{ 生後 1 週間以内 } & \multicolumn{2}{|c|}{1 力月目 } & \multicolumn{2}{|c|}{2 力月目 } & \multicolumn{2}{|c|}{3 力月目 } \\
\hline & 反応 & 潜時 (秒) & 反応 & 潜時 (秒) & 反応 & 潜時 (秒) & 反応 & 潜時(秒) \\
\hline YY & $\mathrm{AI}$ & 9 & AI & 7 & $\mathrm{AA}$ & 4 & $\mathrm{~N}$ & \\
\hline FK & $\mathrm{AI}$ & 5 & AI & 1 & $\mathrm{AI}$ & 2 & $\mathrm{AA}$ & 6 \\
\hline TT & $\mathrm{AI}$ & 15 & $\mathrm{AI}$ & 33 & A I & 2 & $\dot{\mathrm{AA}}$ & 4 \\
\hline $\mathrm{KY}$ & AI & 7 & AI & 2 & $\mathrm{AA}$ & 1 & $\mathrm{~N}$ & \\
\hline MA & AI & 9 & AI & 2 & AA & 4 & $\mathrm{AA}$ & 5 \\
\hline MM & AI & 6 & $\mathrm{AI}$ & 3 & $\mathrm{~N}$ & & $\mathrm{~N}$ & \\
\hline HR & AI & 7 & $\mathrm{Al}$ & 4 & $\mathrm{AA}$ & 4 & $\mathrm{AA}$ & 6 \\
\hline WM & AI & 16 & $\mathrm{AI}$ & 10 & $\mathrm{AA}$ & 5 & $\mathrm{~N}$ & \\
\hline YY & AI & 15 & $\mathrm{Al}$ & 2 & AA & 1 & $\mathrm{~N}$ & \\
\hline HK & AI & 11 & $\mathrm{AI}$ & 6 & A I & 1 & $\mathrm{AA}$ & 1 \\
\hline $\mathrm{MH}$ & $\mathrm{AI}$ & 5 & $\mathrm{AI}$ & 5 & $\mathrm{AA}$ & 2 & $\mathrm{AA}$ & 4 \\
\hline SN & AI & 11 & $\mathrm{AI}$ & 3 & AI & 5 & $\mathrm{~N}$ & \\
\hline IK & AI & 6 & $\mathrm{AI}$ & 4 & A I & 8 & $\mathrm{~N}$ & \\
\hline WS & AI & 10 & $\mathrm{AI}$ & 2 & A I & 6 & $\mathrm{AA}$ & 5 \\
\hline $\mathrm{KY}$ & AI & 20 & AI & 12 & $\mathrm{~N}$ & & $\mathrm{~N}$ & \\
\hline
\end{tabular}

AI : Alert Inactivity で泣き止む

AA:Alert Activity で泣き止む

$\mathrm{N}: \mathrm{NO}$ response

表 7 胎内音 $(90 \mathrm{dBSPL})$ に対し Alert Inactivity になる被験児の時期別割合

\begin{tabular}{ccccc}
\hline & 生 後 & 1 力月 & 2 力月 & 3 力月 \\
& 1 週間以内 & & & \\
\hline 人数 & $15 / 15$ & $15 / 15$ & $6 / 15$ & $0 / 15$ \\
$\%$ & 100 & 100 & 40 & 0 \\
\hline
\end{tabular}

の帯域ごとの聴力測定にこれらを利用することができ ないことが明らかとなった。表 $10 は 0.5,1 ， 2,4 \mathrm{kHz}$ High pass noise \& Low pass noise tape に対する新生 児12名の反応結果であり，これをまとめると表11，図 10のようになる。被験児達は $1 \mathrm{kHz}$ 以下の低音成分を より多く含んで構成された成分音に，より良く反応を 示していることが明瞭である。また“机んころりん” の原音に最も反応が良いことも明らかとなった。

（V）他の音源による聴性反射との反応率の比較

表12に各検査に対する家庭訪問時期（生後日数）別 の反庞を記した。これを図示すると図11のごとくなる。

この調查より各検查における反応不明児の割合をさ らに簡略化すると図12のようになり,胎内音 $1 / 206(0.5$ $\%)$, 舌うち音 $37 / 129$ (28.7\%)，木イッスル音66/ $207(31.9 \%)$ ，紙もみ音73/210（34.8\%）となってい
表 8 生後 3 力月までの時期別胎内音 最小反応音圧レベル

\begin{tabular}{|c|c|c|c|c|}
\hline 被験者 & $\begin{array}{l}\text { 生 後 } \\
1 \text { 造間以内 }\end{array}$ & 1 力月目 & 2 力月目 & 3 力月目 \\
\hline YY & 90 & 70 & $(70)$ & - \\
\hline FK & 90 & 70 & 70 & (90) \\
\hline $\mathrm{TT}$ & 90 & 80 & 60 & $(90)$ \\
\hline KY & 90 & 80 & $(60)$ & - \\
\hline $\mathrm{MA}$ & 90 & 65 & $(80)$ & $(80)$ \\
\hline $\mathrm{MM}$ & 90 & 70 & - & - \\
\hline HR & 90 & 70 & $(80)$ & $(90)$ \\
\hline WM & 90 & 75 & $(60)$ & - \\
\hline YY & 90 & 70 & $(60)$ & - \\
\hline HK & 90 & 80 & 60 & $(70)$ \\
\hline $\mathrm{MH}$ & 90 & 70 & $(75)$ & $(80)$ \\
\hline $\mathrm{SN}$ & 80 & 75 & 70 & - \\
\hline IK & 90 & 70 & 70 & - \\
\hline WS & 90 & 70 & 70 & $(70)$ \\
\hline $\mathrm{KY}$ & 90 & 70 & - & - \\
\hline
\end{tabular}

た。これらより胎内音によるものと，他の椧查を $\chi^{2}$ 検 定すると有意 $(\mathrm{P}<0.001)$ に反応不明者が少なく，そ 
表 9 各新生児の各 $1 / 3$ オクターブバンドノイズに対する反応

\begin{tabular}{|c|c|c|c|c|c|c|}
\hline \multirow{2}{*}{ BABY } & $\begin{array}{l}\text { 生後経過 } \\
\text { 日 数 }\end{array}$ & \multirow{2}{*}{$\begin{array}{l}\text { 胎内音 } 90 \mathrm{~dB} \\
\text { 反応潜時 (秒) }\end{array}$} & \multicolumn{4}{|c|}{ 1ノ3オクターブバンドノイズ } \\
\hline & 日 数 & & $0.5 \mathrm{kHz}$ & $1 \mathrm{kHz}$ & $2 \mathrm{kHz}$ & $4 \mathrm{kHz}$ \\
\hline H.S. & 2 日目 & 21 & $?$ & $(-)$ & $(-)$ & $(-)$ \\
\hline T.H. & 2 日目 & 8 & $(-)$ & $(-)$ & $(-)$ & $(-)$ \\
\hline D.K. & 2 日目 & 7 & $(-)$ & $(-)$ & $(-)$ & $(-)$ \\
\hline K.S. & 2 日目 & 14 & $(-)$ & $(-)$ & $(-)$ & $(-)$ \\
\hline T.M. & 2 日目 & 12 & $(-)$ & $(-)$ & $(-)$ & $(-)$ \\
\hline Y.K. & 2 日目 & 15 & $(-)$ & $(-)$ & $(-)$ & $(-)$ \\
\hline M.Y. & 2 日目 & 9 & $(-)$ & $(-)$ & $(-)$ & $(-)$ \\
\hline S.K. & 3 日目 & 4 & $(-)$ & $(-)$ & $(-)$ & $(-)$ \\
\hline O.T. & 3 日目 & 3 & $(+)$ & $(-)$ & $(-)$ & $(-)$ \\
\hline I.T. & 3 日目 & 9 & $(-)$ & $(-)$ & $(-)$ & $(-)$ \\
\hline T.S. & 3 日目 & 15 & $(-)$ & $(-)$ & $(-)$ & $(-)$ \\
\hline M.N. & 3 日目 & 11 & $(-)$ & $(-)$ & $(-)$ & $(-)$ \\
\hline K.C. & 3 日目 & 14 & $(-)$ & $(-)$ & $(-)$ & $(-)$ \\
\hline I.K. & 3 日目 & 8 & $(-)$ & $(-)$ & $(-)$ & $(-)$ \\
\hline N.J. & 3 日目 & 9 & $(-)$ & $(-)$ & $(-)$ & $(-)$ \\
\hline N.T. & 4 日目 & 4 & $(-)$ & $(-)$ & $(-)$ & $(-)$ \\
\hline I.K. & 4 日目 & 5 & $(-)$ & $(-)$ & $(-)$ & $(-)$ \\
\hline T.Y. & 4 日目 & 17 & $?$ & $(-)$ & $(-)$ & $(-)$ \\
\hline K.N. & 5 日目 & 19 & $(-)$ & $(-)$ & $(-)$ & $(-)$ \\
\hline S.M. & 5 日目 & 24 & $(-)$ & $(-)$ & $(-)$ & $(-)$ \\
\hline H.H. & 5 日目 & 27 & $(-)$ & $(-)$ & $(-)$ & $(-)$ \\
\hline S.Y. & 5 日目 & 17 & $(-)$ & $(-)$ & $(-)$ & $(-)$ \\
\hline K.M. & 7 日目 & 23 & $(-)$ & $(-)$ & $(-)$ & $(-)$ \\
\hline N.R. & 10 日目 & 26 & $?$ & $(-)$ & $(-)$ & $(-)$ \\
\hline T.K. & 12 日目 & 22 & $(-)$ & $(-)$ & $(-)$ & $(-)$ \\
\hline
\end{tabular}

(+):泣き止んでAlert Inactivityになった (一): 1 分以内に泣き止まなかった

?:自然に泣き止んだのか, 反応して泣き 止んだのか判断に迷った

の判定が容易であることが明らかとなった。

\section{考察}

胎内音は母体大動脈血流音, 母体心音, 臍带雑音, 腸雑音, 胎児心音などによって構成されている warble toneである.その存在は1971年より知られていた が, 1974年室岡は,これらの音を録音して泣いている 新生児に呈示すると泣きやみ鎮静効果があることを報 告した9．また，この時の胎内音は母体大動脈血流音を 主体としたものであり，後に作成した胎児性胎内音の 方が鎮静効果が高いことを明らかにした ${ }^{10)}$. 今回使用 した音源発生装置 “极んころりん”は胎児性胎内音を
主体としたもので，1分間に 144 beat を持つwarble toneである.

胎内音による鎮静効果は，室岡 ${ }^{10)}$ によれば，母体大 動脈性胎内音では300人中258人 (86\%), 胎児性のもの では100人中 90 人 (90\%) であり，その効果の有意性に つき言及している，またRosner ら”) は室岡の作成し た母体大動脈音を主体とした胎内音を用いて客観的に 観察した結果 $90 \% の$ 鎮静効果が認められたことを報告 している.今回の検查成績より高度難聴児 2 名を除い た150名の反応を検討すると, 80,90dBSPLの反応陽 性児は133名 (89\%) と彼らの呈示した音圧レベルでの 鎮静反応陽性率とほぼ一致している。 
表10 High pass noise, Low pass noise に対する各被験児の反応結果

\begin{tabular}{lccccccccccc}
\hline \multirow{2}{*}{ BABY } & \multicolumn{2}{c}{ 生後経過 } & 胎内音 $90 \mathrm{~dB}$ & \multicolumn{3}{c}{ HIGH PASS NOISE } & \multicolumn{5}{c}{ LOW PASS NOISE } \\
& 日 & 数 & 反応潜時(秒) & 0.5 & 1 & 2 & $4(\mathrm{kHz})$ & 0.5 & 1 & 2 & $4(\mathrm{kHz})$ \\
\hline Y.H. & 2 日目 & 17 & 20 & $(-)$ & $(-)$ & $(-)$ & 37 & 19 & 20 & 15 \\
H.S. & 2 日目 & 5 & $(-)$ & $(-)$ & $(-)$ & $(-)$ & $(-)$ & 28 & 47 & 11 \\
M.H. & 2 日目 & 10 & 24 & $(-)$ & $(-)$ & $(-)$ & 25 & 28 & 11 & 10 \\
K.T. & 3 日目 & 12 & $(-)$ & $(-)$ & $(-)$ & $(-)$ & $(-)$ & 47 & $(-)$ & $(-)$ \\
Y.S. & 3 日目 & 8 & 24 & $(-)$ & 30 & $(-)$ & 19 & 9 & 11 & 12 \\
T.M. & 4 日目 & 14 & 26 & 40 & $(-)$ & $(-)$ & $(-)$ & 29 & 30 & 29 \\
T.I. & 4 日目 & 8 & $(-)$ & $(-)$ & $(-)$ & $(-)$ & $(-)$ & $(-)$ & 23 & 51 \\
T.M. & 4 日目 & 5 & 9 & $(-)$ & $(-)$ & $(-)$ & 13 & 9 & 5 & 5 \\
O.H. & 4 日目 & 12 & 14 & $(-)$ & $(-)$ & $(-)$ & $(-)$ & 10 & 17 & 7 \\
S.K. & 4 日目 & 21 & $(-)$ & $(-)$ & $(-)$ & $(-)$ & 10 & 12 & 12 & 7 \\
H.T. & 5 日目 & 17 & 51 & 37 & $(-)$ & $(-)$ & 11 & 5 & 27 & 12 \\
W.F. & 6 日目 & 25 & 35 & $(-)$ & $(-)$ & $(-)$ & $(-)$ & $(-)$ & 42 & 17 \\
\hline
\end{tabular}

各数字は反応陽性児の反応潜時を示す。

表11 High pass noise, Low pass noiseに対する反応のまとめ

\begin{tabular}{lrrrrrrrr}
\hline & \multicolumn{4}{c}{ HIGH PASS NOISE } & \multicolumn{3}{c}{ LOW PASS NOISE } \\
\hline & 0.5 & \multicolumn{1}{c}{1} & 2 & $4(\mathrm{kHz})$ & 0.5 & 1 & 2 & $4(\mathrm{kHz})$ \\
\hline 反応陽性児 & 8 & 2 & 1 & $0($ 名) & 6 & 10 & 11 & 11 (名) \\
反応陰性児 & 4 & 10 & 11 & $12($ 名) & 6 & 2 & 1 & 1 (名) \\
陽 性 率 & 67 & 17 & 9 & $0(\%)$ & 50 & 83 & 92 & $92(\%)$ \\
\hline
\end{tabular}

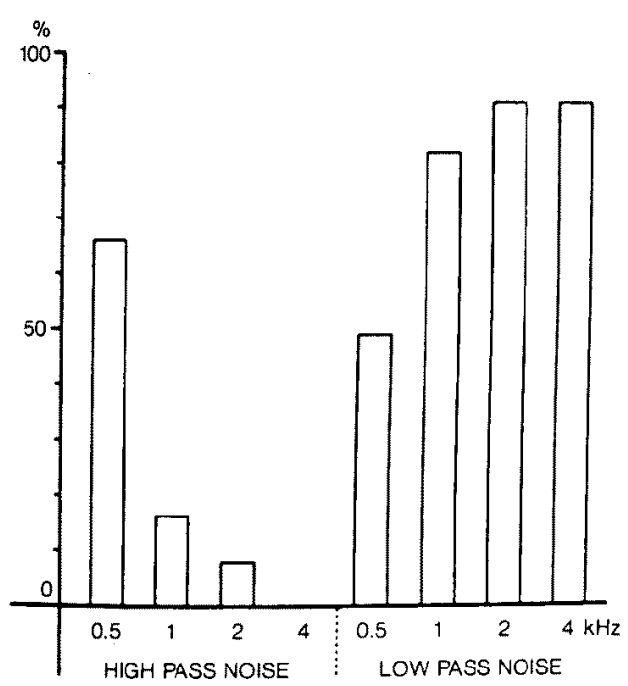

国10 High pass noise, Low pass noise に対す る反応陽性率
胎内音の新生児に対する鎮静効果が聴性反応である うと, 室岡 ${ }^{11)}$, Rosner ら ${ }^{9)}$ は考察しているが確たる証 明はなされていない.今回の ABRに反応陽性で，6歳 の時点で聴力に問題なく日常生活を送っている67名中 65名が胎内音に対し反応陽性であり，また $\mathrm{ABR}$, 胎内 音にも反応の認められなかった高度難聴児 2 名も考慮

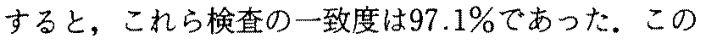
ことから胎内音に対する反応が聴性反応であることを 証明できたと考える。

この胎内音に対寸る聴性反応が生後何力月頃まで典 型的に出現するものか，またその反応潜時や反応音圧 レベルについて検討した結果, 生後 1 力までは这い ている児が全員典型的に alert inactivityに泣さ止む 現象が認められた。しかし，2力月目には反応の認め られない児が存在し始め，泣き止んでも alert activity を呈する児が増加してきていた，3力月目には典型的 な反応は皆無になっていた。これらの現象には，baby が運動能力の発達に伴い音源方向老探索する反応の増 
表12 各検查に対する家庭訪問時期別の反応

胎 内音検 查 児

\begin{tabular}{|c|c|c|c|c|c|c|c|c|c|c|c|c|c|c|c|}
\hline $\begin{array}{l}\text { 検 } \\
\text { 反 } \\
\text { 意 } \\
\text { 時 } \\
\text { 期 }\end{array}$ & $\begin{array}{l}0 \\
3 \\
6\end{array}$ & $\begin{array}{c}7 \\
13\end{array}$ & $\begin{array}{c}14 \\
20\end{array}$ & $\begin{array}{c}21 \\
27\end{array}$ & $\begin{array}{c}28 \\
3 \\
34\end{array}$ & $\underset{41}{35}$ & $\int_{48}^{42}$ & $\int_{55}^{49}$ & $\begin{array}{c}56 \\
\text { S } \\
62\end{array}$ & $\begin{array}{c}63 \\
6 \\
69\end{array}$ & $\int_{76}^{70}$ & $\int_{83}^{77}$ & $\int_{90}^{84}$ & $\begin{array}{c}91 \\
3\end{array}$ & 計 \\
\hline 有 & 0 & 2 & 2 & 5 & 13 & 27 & 43 & 41 & 40 & 12 & 10 & 6 & 0 & 2 & 203 \\
\hline 無 & 0 & 0 & 0 & 0 & 1 & 0 & 0 & 0 & 1 & 0 & 0 & 0 & 0 & 0 & 2 \\
\hline 不 明 & 0 & 0 & 0 & 0 & 0 & 0 & 0 & 0 & 1 & 0 & 0 & 0 & 0 & 0 & 1 \\
\hline 未害施 & 0 & 0 & 0 & 0 & 3 & 2 & 3 & 3 & 5 & 3 & 0 & 0 & 0 & 0 & 19 \\
\hline 計 & 0 & 2 & 2 & 5 & 17 & 29 & 46 & 44 & 47 & 15 & 10 & 6 & 0 & 2 & 225 名 \\
\hline
\end{tabular}

\begin{tabular}{|c|c|c|c|c|c|c|c|c|c|c|c|c|c|c|c|}
\hline & 0 & 7 & 14 & 21 & 28 & 35 & 42 & 49 & 56 & 63 & 70 & 77 & 84 & 91 & \\
\hline 時 & S & S & S & \} & \} & $\zeta$ & $\int$ & S & S & S & S & S & $S$ & $\int$ & 計 \\
\hline 空 & 6 & 13 & 20 & 27 & 34 & 41 & 48 & 55 & 62 & 69 & 76 & 83 & 90 & & \\
\hline
\end{tabular}

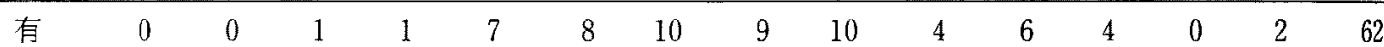

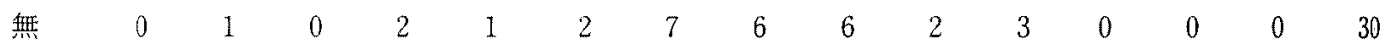

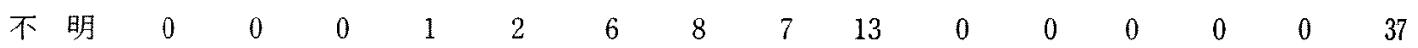

$\begin{array}{llllllllllllllll}\text { 未実施 } & 0 & 1 & 1 & 1 & 7 & 13 & 21 & 22 & 18 & 9 & 1 & 2 & 0 & 0 & 96\end{array}$

$\begin{array}{llllllllllllllll}\text { 計 } & 0 & 2 & 2 & 5 & 17 & 29 & 46 & 44 & 47 & 15 & 10 & 6 & 0 & 2 & 225 \text { 名 }\end{array}$

\section{木イッスル検查児}

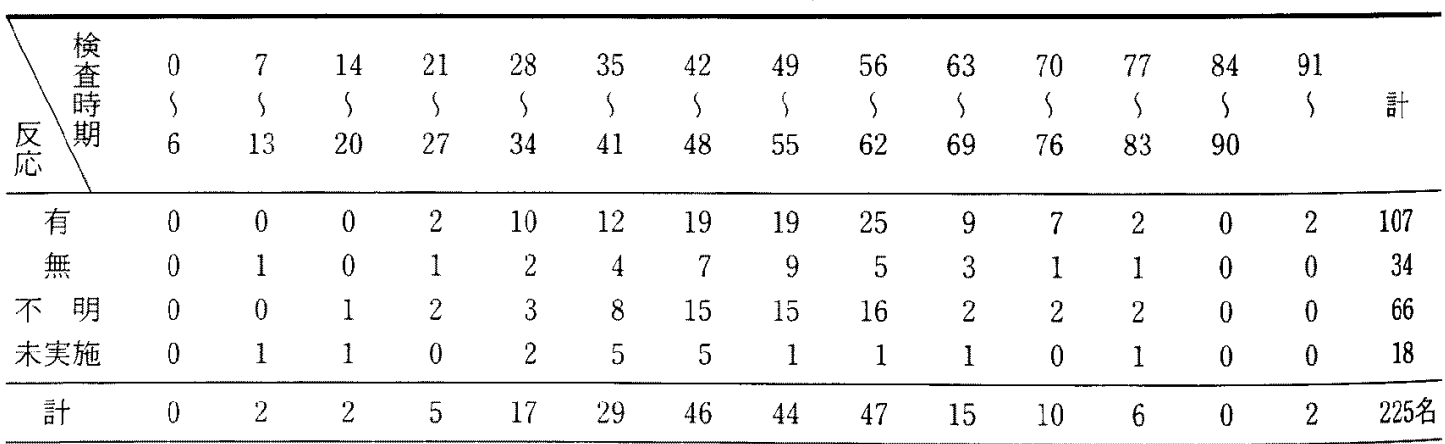

紙も み音検查坚

\begin{tabular}{|c|c|c|c|c|c|c|c|c|c|c|c|c|c|c|c|}
\hline 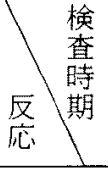 & $\begin{array}{l}0 \\
6 \\
6\end{array}$ & $\begin{array}{c}7 \\
5 \\
13\end{array}$ & $\begin{array}{c}14 \\
20\end{array}$ & $\begin{array}{c}21 \\
27\end{array}$ & $\begin{array}{c}28 \\
34 \\
34\end{array}$ & $\underset{41}{35}$ & $\int_{48}^{42}$ & $\int_{55}^{49}$ & $\int_{62}^{56}$ & $\begin{array}{c}63 \\
\text { S }\end{array}$ & $\begin{array}{c}70 \\
\text { S }\end{array}$ & $\begin{array}{c}77 \\
8\end{array}$ & $\begin{array}{c}84 \\
90\end{array}$ & $\begin{array}{c}91 \\
\}\end{array}$ & 計 \\
\hline 有 & 0 & 0 & 0 & 3 & 7 & 9 & 18 & 20 & 22 & 10 & 6 & 4 & 0 & 2 & 101 \\
\hline 無 & 0 & 1 & 1 & 0 & 2 & 3 & 10 & 7 & 5 & 4 & 3 & 0 & 0 & 0 & 36 \\
\hline 不 明 & 0 & 0 & 1 & 2 & 5 & 13 & 14 & 16 & 20 & 0 & 1 & 1 & 0 & 0 & 73 \\
\hline 未実施 & 0 & 1 & 0 & 0 & 3 & 4 & 4 & 1 & 0 & 1 & 0 & 1 & 0 & 0 & 15 \\
\hline 計 & 0 & 2 & 2 & 5 & 17 & 29 & 46 & 44 & 47 & 15 & 10 & 6 & 0 & 2 & 225名 \\
\hline
\end{tabular}



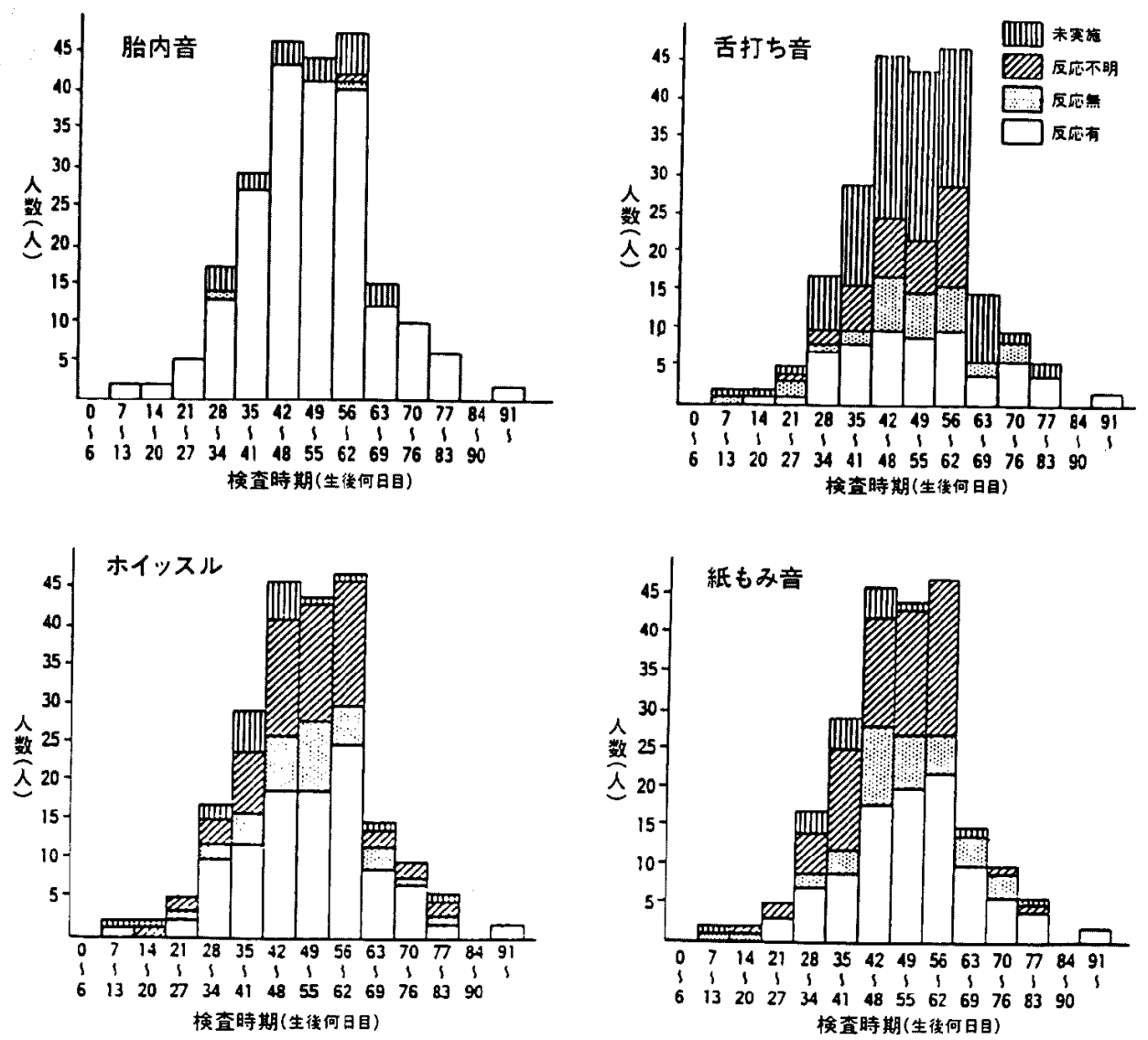

図11 各検查に対する家庭訪問時期別の反応
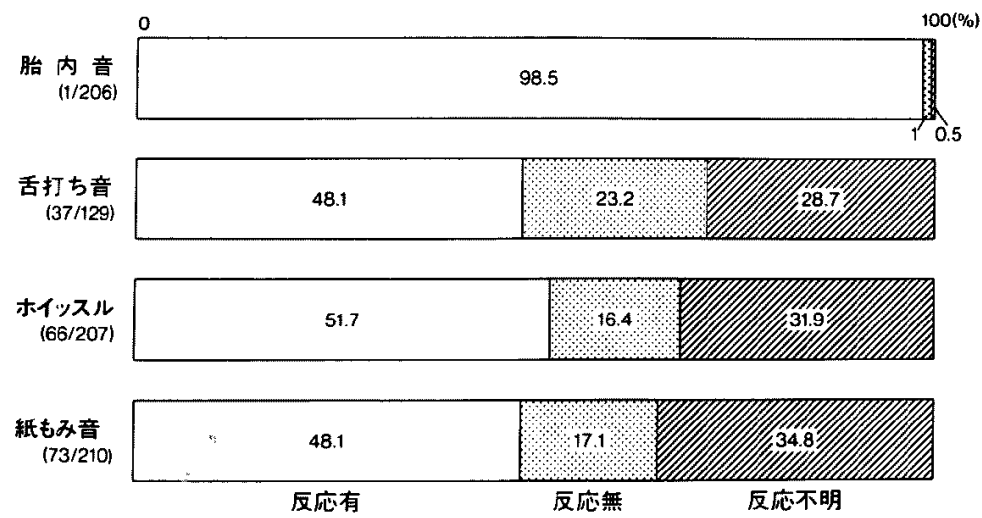

図12 各㭘查の反応別割合

加も関与しているように思える。

反応潜時については, 生後 1 カ月の時点での短縮は, それぞれの児の聴覚路の成熟を反映したものと考えら れる.
2 カ月目からの域值上昇に関しては, 生後の胎外適 応による他の音との混乱, 児自身の泣き声の強大化に よるマスキング効果の増大などによるものが推測でき る. 
これらの結果より，この胎内音を用いての聴覚検查 は生後 1 力月以内に実施されることが望ましいと結論 できた。

胎内音から抽出した1/3オクターブバンドノイズの 狭帯域成分に対して, 新生児達はほとんど反応を示さ ずこれらのノイズを聴力測定に利用することができ ないことも明らかとなった。 またこの胎内音に対す る反応には $1 \mathrm{kHz}$ 以下の低音成分が大きく関与し, 室 岡 $^{4)}$ の「子宮内の環境は, 外界加ら入てくる音も加 え, 低音優勢高音隇衰となっている.」との報告を裏づ ける結果となった。

しかし，胎内音に対する新生児の反応が，どのよう な聴覚反射経路によって誘起されるのであろうか？

この反応の平均潜時が $12 \pm 7.4 \mathrm{sec}$. であることよ り，新生児期に一般的に観察されるモロー反射，聴性 眼瞼反射, 党醒反射, 定位反射などの脳幹レベルの筋 反射に基づく純反射的なもの ${ }^{12\}}$ とは明らかに異なっ た，さらに高位の反応であることは確かである。 Salk ${ }^{13)}$ は imprintingによると考え，Bench ${ }^{14)}$ は胎内 音の低周波数成分が泣き声をマスクしてしまうためだ としている.またこれら以外に胎内での学習によると いう説もある9.しかし，まず imprintingであればこの 反応はもっと永続的なものでなければならず，泣き声 の masking 説にしても泣き声の成分が $4 \mathrm{kHz}$ 以上も

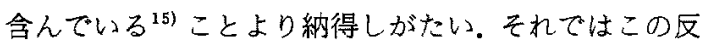
応は，胎内での学習によるものであるうか？その典 型的な反応性生後 1 力月までしか認められず 2 力月目 からは泣き止まない児も出現してくるという事実，ま たこの胎内音を生後聴かし続けることにより，この反 応が長期にわたって継続して残存して行くとは思われ ないことなどを考えあわせると学習説も否定的であ る.これらのことよりこの反応のメカニズム解明は， 今後の神経発達学的研究を待た秝ばならない。

次いで，この反応がスクリーニング検查として実際 に利用されるためには聴覚㭘査に末経験な人々にとっ ても容易に実施可能な検査でなければならない。本研 究では保健婦の協力を得てこの点を明らかにしたいと 考えた．その結果，成績で述べたごとく，従来からの 聴性反射を直接観察する方法よりも有意にその反応の 判定が容易であることが明らかとなり，地域保健活動 の一環として本法評侕し位置付けることが出来たと 考える。

現在の世界的動向として, 新生児期の聴賞スクリー ニング検查は，リスク児中心法で夷施されている。こ
の方針は1974年の Nova Scota (カナダ)の Halifaxで 開催された国際会議での勧告によるものである。ここ にいうリスク児とは，

(1) 家族歴に遺伝性難聴のあるもの.

(2) 風疹ないし非細菌性の子宮内胎児感染例。

(3) 耳鼻咽喉科領域に奇形のあるもの.

(4) 生下児体重 $1,500 \mathrm{~g}$ 以下のもの.

(5) 血清ビリルビン值 $20 \mathrm{mg} / \mathrm{dl}$ 以上のもの. である16. しかしリスク児中心法は、あくまでも満足さ れる心゙き悉皆検查法が確立されるまでの暫定的なもの である，今回この論文で述べてきた胎内音を用いての 方法は高度難㯖児スクリーニング悉皆検查法として, 分婏入院期間中の新生児全員に施行することが可能な ことが明らかとなった。

スクリーニング検査には「取り込みすぎ、「取りこ ぼし」という現象が必ず付きまとう。この検查につい ては，（II）の結果より反応の有無の判定に迷ったこの ような例を「取り込みすぎ」に入れると，その割合は 67名の被験児中 2 名 $3 \%$ に認められることになる。取 りこほし」については，当科の外来は地域性が強〈熊 学校との連絡も密なため和歌山県下の高度難聴児の把 握が容易であるが，この研究での対象児の中から峙出 現してきていない，しかしこの検査は高度難聴児にの み適応があると考えていることや，新生児期以後に難 聴の発生する可能性を考慮すると，上り正確に難聴児 を早期発見するには，本法のみならず舌打ち音を用い た入眠時開眼反応 ${ }^{7}$, 田中・進藤の聴覚発達チェックリ

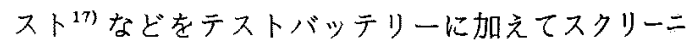
ング検査を体系的に継続して実施していかなくてはな らない。また，このようなスクリーニング検查の結果 が保健所活動の一環としてチェックできるようなシス テム化の確立が必要であると考える.

\section{まとぬ}

1. その主な周波数領域が1/3オクターブパンド $400 \mathrm{~Hz} \sim 4 \mathrm{kHz}$ の胎内音を 152 名の新生児に聴かせ反 応陽性児148名，反応陰性児 2 名，反応不明児 2 名加観 察された。陰性児 2 名は高度難聴児であった。またこ の内の69名には ABR も実施され，その反応は胎内音 による反応とよく一致していた。

2. 新生児が胎内音に反応して泣きやみ alert inactivityになる現象は生後 1 力月頃まで認められ，を の反応域值は生後 1 週間までのものより小さなって おり，潜時についても短縮傾向が認められた。 
3. 1/3オクターブバンドノイズ $0.5 \mathrm{kHz}, 1 \mathrm{kHz}$, $2 \mathrm{kHz}, 4 \mathrm{kHz}$ の成分テープにはほとんど反応を認めな かった. High pass noise, Low pass noise の成分テ 一プの検討より低周波数成分をより多く含んでいるほ うが反応率が良かった。

4. 胎内音による検査は舌うち音, ホイッスル音, 紙もみ音による検査より反応の判定が容易なことが明 らかとなった。

\section{結語}

胎内音を内臓した人形“机ころりん”を用いての 新生児の聴覚反応を観察した今回の研究によりこの反 応が高度難聴児のスクリーニング検査として有用であ るとともに，その検査時期は 1 力月以内が望ましいと 言える.

\section{参考文献}

1）田中美郷：新生児聴力検查. 日耳鼻補冊 5:63-67, 1969.

2) Simmons FB, Russ NF : Automated hearing screen. ing technique for newborns. Arch Otolaryngol $100: 1-7,1974$.

3）田中美郷，阿波野安幸，坂本正二: Neonatal Audiometer による新生児の聴性反応の観察。Audiol Japan 26(4) : 279-280, 1983 .

4）室閏一,佐々木 毅, 中村三和, 松本次郎, 若麻續佳樹 胎内音の新生児に及ぼす影響，小児科 $20: 259-265$, 1979.

5）加藤 寛, 田中佐代子, 田端敏秀：胎内音に対する新生 児の聴覚反応，耳鼻臨床 $77(6) ： 1367-1373 ， 1984$.

6) 加藤 寛, 田中佐代子, 田端敏秀: 胎内音に対する新生 児聴覚反応の経時的変化. Audiol Japan 28:744-748, 1985.

7) 鈴木重忠, 能登谷晶子：入眠時聴性開眼反応. Audiol Japan 23 : 26-33, 1980.

8) Walker D, Grimwade J, Wood C: Intrauterine noise; a component of the fetal environment. Amer J Obstetrics Gynecology 109 : 91-95, 1971.
9) Rosner BS, Doherty NE: The Response of Neonates to Intra-uterine Sound. Develop Med Child Neurol $21: 723-729,1979$.

10）室岡 一: ママの执なの子守歌，東芝EMI K.K. (TW-80010) 1-8.

11）室岡 一：新生児と音. 助産婦雑誌 $33: 189-192$, 1979 .

12）加我君孝, 田中美珋：新生児聴力障害スクリーニング. 産婦人科の実際 $29: 99-108,1980$.

13) Salk $L$ : Mothers' heartbeat as an imprinting stimulus. Transactions of the New York Academy of Science $24: 753-763,1962$.

14) Bench $\mathrm{J}$ : Some effect of audio-frequency stimulation on the crying baby. Journal of Auditory Research 9: 122-128, 1969.

15) Truby HM, Lind J: Cry sound of the newborn infant. Acta Paediatrica Scandinavica, Supplement $163: 7-59,1967$.

16）鈴木篤郎，田中美郷 : 幼児難聴; 幼坚難聴の検出と診 断. 医薯菜出版, 東京, 1979, 99-139頁.

17）田中美郷，小林はるよ, 進藤美津子, 加我君孝: 乳児の 聴覚発達検查とその臨床および難聴児早期スクリーニ ングへの応用. Audiol Japan $21: 52-73,1978$.

稿を終えるにあたり、ご指導と御校閱を賜りました田端 敏秀教授に深く感謝の意を捧げます。また適切な御教示を 戴いた帝京大学田中美郷教授, 和歌山県立医科大学衛生学 教室武田真太郎教授，松本健治講師に，さらに御坊保健所管 内の柏木真弓美氏ほか18名の保健婦さん達に謝意を表しま 寸.

なお，本論文の一部は昭和61年度文部省科学研究費将励 研究 A. No. 61771320, 昭和59，60，61年度厚生省心身障害 研究「身体障害児の療育に関する研究，一聴覚言語障害児の 療育に関する研究（田中美郷班）一」の援助を受けた。

（1989年10月18日受稿１989年12月19日受理 急載） 別刷請求先 $=640$ 和歌山市七番町 27 和歌山県立医科大学耳鼻咽喉科学教室 加藤 宽 